\title{
Conflict Management Strategies and Their Relationships with Employees' Achievement Motivation at Al-Hussein Bin Talal University (AHU)
}

\author{
Dima Waswas (Corresponding author) \\ Curriculum and Instruction Department \\ Al-Hussein Bin Talal University \\ Ma’an, Jordan \\ Tel:962-77-730-5580Ｅ-mail:dmwaswas@yahoo.com
}

\author{
Muna Abu-Darwish \\ Special Education Department \\ Al-Hussein Bin Talal University \\ Ma'an, Jordan \\ Tel: 962-77-796-1538_E-mail: monaabudarwish@yahoo.com
}

Received: December 27, 2017 Accepted: January 27, 2018 Published: February 8, 2018

doi:10.5296/ijld.v8i1.12375 URL: https://doi.org/10.5296/ijld.v8i1.12375

\begin{abstract}
This study aimed at identifying the level to which the administration at Al-Hussein Bin Tala (AHU) uses conflict management strategies and its relation to achievement motivation among its employees. To achieve the purposes of this study the researchers developed a scale that includes three parts: demographic information, (27) items measuring conflict management strategies and (20) items measuring achievement motivation. Validity and reliability were accredited the scale was applied to a sample of (149) academic administrative employees and only administrative employees who were randomly assigned.

The results revealed that the means of conflict management strategies scale range from (2.634) to (3.369) at moderate level. Result also showed that there are no statistically significant
\end{abstract}


differences at conflict management scale related to gender, job type and the number of years in administrative experience. However, the result revealed higher levels of achievement motivation means range from (4.651) to (4.013). Finally it was indicated that there was a significant positive but low relation between avoiding strategy and the achievement motivation while there was no significant relation between the use of the other strategies and achievement motivation.

Keywords: conflict management strategies, achievement motivation, Al-Hussein Bin Talal University

\section{Introduction}

\subsection{Organizational Conflict}

Modern management theories consider organizational conflict as inevitable phenomenon in organizations. They anticipated that the lack of conflict or low intensity conflict in an organization would cause stagnation. In addition, the existence of high intensity conflict in an organization is harmful. High intensity conflict limits collaboration among organization's employees. Wherever there are interactions among individuals and groups within an organization, there are conflicts are inevitable (Harem, 2006).

The traditional management systems consider organizational conflict as preventable situation that need to be avoided. They consider organizational conflict as an outcome of personal differences or leadership failure. From the perspective of traditional management systems, organizational conflicts can be managed by leaders' direct intervention or by the separation of conflicting parties.

However, the modern management systems consider organizational conflicts as natural outcomes of organizational interaction. From the perspective of modern management systems, organizational conflicts originate from the complexities within the organizations. Organizational conflicts may bring positive change in an organization, where many administrators have positive perceptions of and attitudes toward organizational conflicts. A study has shown that some administrators considered managing conflicts in their organizations almost as important as managing any other administrative tasks, where these administrators believed that spending about $20 \%$ of their management time in managing conflicts is ordinary because of the perceived importance of conflicts within an organization. They believed that this amount time, devoted for managing organizational conflicts, was is not wasted time and was not too much (Hassan, 1999).

The modern view of organizational conflict considers conflicts as real, positive, inevitable phenomenon that cannot be avoided. In addition, the outcomes of organizational conflict can be negative or positive according to the ways of handling and managing such conflicts (Al-Momani, 2011).

Conflicts benefit organization, since conflicts lead to change and lead to form positive forces that might improve employees' performance and efficiency in an organization (Al-Harbi, 2008). In organization, an effective management strategy is to maintain conflicts within 
desired framework and levels. If the intensity of conflicts increase or decrease above or below the desired levels, the administration should work on maintaining the levels of the intensity of conflicts. Moreover, the administration should keep the levels of organizational conflicts under control, where the administration should continuously manage the conflicts in order to achieve desired administrative goals and objectives (Hammoud, 2002)

Managing organizational conflicts does not necessary mean terminating conflicts or reducing the intensity of conflicts. The process of managing organizational conflicts starts with diagnosing the conflicts in order to determine their levels. Based on the results of the diagnostic process, the administration should act. When organizational conflicts are not existing or when organizational conflicts have low levels of intensity, the administration should create organizational conflicts or increase the levels of intensity of organizational conflicts. While, when organizational conflicts have high levels of intensity, the administration should reduce the levels of intensity of the conflicts (Al-Ababneh, 1995).

The organizational conflicts might hinder the achievement of the desired organization's objectives and goals. This is particularly true, when the causes of the conflicts are related to defending employees' personal interests rather than being related to defending organization's interests and goals (Ayazra \& Beni-Ahmed, 2008). On the other side, organizational conflict might be positive and useful. It is not recommended for administration to intervene in the organizational conflicts when these conflicts have positive consequences for the organization. Therefore, administration should intervene to manage organizational conflicts in two cases:

First, when the intensity of the conflicts exceeds the desired levels, it is the responsibility of the administration to intervene to reduce the intensity of conflicts to the desired levels. Second, when the intensity of conflicts falls short of the desired levels, it is the responsibility of the administration to intervene to increase the intensity of conflicts to the desired levels (Al-Mograbi, 1994, p. 310).

Researchers had different definitions of conflict based on the intellectual school to which they belong to. Robbins (2001) defined conflict as "the process that begins when one party perceives that the other has negatively affected, or is about to negatively affect, something that he or she cares about" (p. 243). Al-Omayan (2005) proposed another definition, where he defined conflict as "the process that begins when one party sees or realizes that the other is obstructing or about to obstruct him/her from achieving something that he or she cares about" (p. 364). In earlier definitions, Hilal (1996) defined the conflict as "variations in purposes, interests or behaviors between employees and their supervisors within an organization" (p. 4) and Jones (1995) defined conflict as "the differences that occur as results from conflicting objectives between one group and another" (p. 500).

The organizational conflicts involve two or more conflicting parties. Any conflict had causes that lead to its occurrence. Conflicting parties have the ability to harm each other (Al-Otaibi, 2006). In an organization, the conflicting parties prefer to engage in dialogues with each others to accomplish their goals. Tension is an essential part of the conflicts that leads the conflicting parties to engage in hostile activities against each other, such hostility imposes heavy burdens and costs on the concerned parties (Katishat, 2006). The outcomes of the 
conflicts remain unknown to any party until the end of the conflict (Al-Otaibi, 2006). The causes for organizational conflicts vary; Al-Omayan (2005) reported some of these reasons:

- Conflict or change in roles: conflicts occur when there are two pressure groups that the employee counters at the same time.

- Change in the powers granted for an individual or a group: conflicts occur when there is an increase or decrease in the levels of powers enjoyed by individual or a group.

- Change in status or position: conflicts and disorder in the organizational structure occur when there is a change in the employee's status and position within organization.

- Duplication or overlap: conflicts occur when two or more employees are required to do the same work.

- Competition for resources: conflicts occur when there is competition between the members of one organization or between different departments over the same available resources.

- Cultural differences: conflicts between individuals or between groups occur when the employees in an organization come from different cultures.

Furthermore, Ayazra and Bani-Ahmed (2008) prposed two more possible causes to conflicts in an organization, these causes include:

- Organizational causes: Conflicts might occur due to the nature of organizational structure, where the relations among different organization's components might play an integral role in the emergence of conflicts. Related example of the cause of organizational conflicts are the existence of multiple administrative levels, the existence overlapping of activities and events, the concentration of power in hands of a few people, and employee's lack of clarity of his/her job profile and description.

- Rumors: conflicts might occur due the spread rumors, where rumor is considered as one of the most dangerous weapons that can destroy individuals and organization and disturb organizational thought and management.

The administration literature shows that the organization administration have used a variety of strategies in order to manage organizational conflicts, these strategies include:

- Dominating strategy: this strategy involves a high level of concern for self and weak a low level of concern for others. The individuals who adopt the dominating strategy use force and coercion to achieve his/her goals and desires without paying attention to the goals and wishes of the others (Katishat, 2006). When the dominating strategy is used in an organization, conflicts are resolved and terminated by direct intervention of higher management through the use of power and authority (Al-Balbisi, 2003).

- Avoiding strategy: this strategy involves withdrawal and evasion from the conflicts (Owens, 1981). It characterized by ignoring conflicting parties' concerns, ignoring the 


\section{MInstitute Macrothin}

causes of conflicts, and keeping conflicts within useful limits.

- Collaborating strategy: this strategy involves the conflicting parties working together to find acceptable conflict resolution to satisfy the interests and demands of all parties. The collaboration takes the form of investing the dispute so that the conflicting parties learn from each other's experience and wisdom (Al-Momani, 2011). Collaboration mode for managing conflicts is one of the ideal approaches to resolve organizational conflicts. However, collaboration approach is difficult to implement as it seeks to resolve the conflicts by applying the utmost attentions to the interests of both parties. The success of this approach requires teamwork from the conflicting parties as well as conflicting parties' positive attitudes toward reconciliation and cooperation (Idris \& Morsi, 2003)

- Accommodating strategy: using this strategy in an organization involves the administration giving up its own interests to achieve the interests of the employees of the organization in order to terminate the causes of conflicts and disagreements (Issa, 2009).

Organizational conflicts have both positive and negative consequences. The positive effects of organizational conflicts include showing employees' latent capabilities and aptitude that do not appear in normal circumstances. Moreover, the organizational conflicts facilitate interaction among the employees and the administration in the organization. Conflict is a type of communication and the process of resolving conflicts opens new and long-lasting channels of communication in the organization. Conflicts might helping identifying organizational problems and contribute in resolving these problems. In addition, conflicts provide basis for creativity and innovation in the organization (Al-Ababneh, 1996). Furthermore, when conflicts are resolved, individuals become more committed to the outcomes of conflict resolution (Harem, 2004).

The negative effects of organizational conflict emerge when each conflicting party care about satisfying their own interests rather than caring about satisfying the organization's interests and accomplishing the goals of the organization. The negative effects of organizational conflict would destroy morale; waste time, effort and money; weaken the level of efficiency and the effectiveness of the organization; impede cooperative work; reduce productivity; and makes the organization's performance suffer from stagnation (Al-Omayan, 2002).

\subsection{Achievement Motivation}

Achievement motivation is individual's desire to do high-quality job and to be successful in that job. Individuals with high level of achievement motivation are characterized by their high levels of ambitions, their feelings of enjoyment in doing competitive work tasks, their preference for working independently, their preference for accomplishing difficult work tasks, and their preference for completing moderate risk tasks rather than low risk tasks (Ghbari, 2008). Individual's need of achievement has two components: the one's desire for achievement and one's fear if failure. The high achievers are individuals who have strong motive to achieve and weak motive to avoid failure. While, low achievers are individuals 
who have strong motive to avoid failure and weak motive to achieve (Al-Zayat, 1988)

There are different definitions of achievement motivation. For instance, Taha (2003) defined achievement motivation as the individual's desire to accomplish his/her assigned work tasks and duties at optimal levels of personal excellence in order to earn respect from supervisors and collogues, to increase income, and to get promotion. Al-Hamed (1996) defined achievement motivation as "the motive to seek success, to achieve desirable results, to overcome barriers, or to complete work tasks efficiently and effectively" (p.134). Al-Haji (1996) defined achievement motivation as "an acquired motivation that emerged from interaction with surrounding environment. It consists of cognitive, emotional, and behavioral drives and encourages individual to achieve specific goals" (p.31).

The individual's attitudes towards achievement are determined by several factors, Khalifa (2000) reported some of these factors:

- Individual's level of enthusiasm for works and for making effort to achieve his/her goals.

- Individual's desire for feeling pride in his/her success and his/her desire to avoid the feeling of shyness and failure.

- Individual's expectations about of the chances of success and failure.

- Individual's perceived values of success or his/her perceptions of the consequences of success or failure.

The study of achievement motivation is of great importance to both, the employees and the organization, Abbas (2002) reported some of the important benefits of study of achievement motivation in an organization:

- Motivations are the drives for the individuals' behavior and performance. Therefore, understanding employees' motivations helps the organization to encourage employees' by appropriate incentives.

- Employees' positive motivations foster greater collaboration between them and organization' administration.

- Employees' positive motivations help to reduce conflicts among them and groups within the organization.

- Employees' positive motivations increase their creativity in work.

- Understanding the nature and the level of individuals' motivation would help in shaping the strategic direction of the organization.

- Understanding the individuals motivations is important to design appropriate training programs (Abbas, 2002)

Individuals with high level of achievement motivation would continuously and naturally set personal goals that involve challenges and risks; where they do not feel accomplished when 
the tasks they perform are easy and have a guaranteed results (Al-Bernouti, 2004). They prefer new and challenging tasks and they avoid routine tasks (Abdulah, 2003). Individuals with high level of achievement motivation are characterized by being high self-confidence and they make moderate to high risk decisions. They tend to be skeptical about views of the people who have more experience than them and they focused on doing the work task itself rather than focusing on the financial return from the completion of the work task.

\subsection{The Relationship between Organizational Conflicts and Achievement Motivation}

Agwu (2013) reported that there was a significant relationship between conflict management strategies and employees' performance. There is a significant relationship between the levels of conflicts and levels of achievements. Moderate levels of conflicts leads to optimal levels of achievements. However, when the levels of conflicts are very low or very high in an organization, the levels of achievement would be low. A successful and modern administration is the one that can deal with the conflicts at the time of their emergence by keeping their intensity at the desired levels through allowing the employees to be involved in managing conflicts and engaging them in decision-making to achieve desired organizational outcome Problem of the Study.

Conflict is an important behavioral phenomenon that is complex and highly intertwined. Conflicts in an organization cannot be neglected by the administrators. Organizational conflict has been considered as one of the most important challenges for administrators that might hinder organization's works. Organizational conflict should be controlled using appropriate management strategies. Otherwise, organizational conflict would take most of the administrators' efforts and time (Mustafa, 2000). Conflict is a human phenomenon that is inevitable. Therefore, successful management is the one that is capable of managing the conflicts and use them as mean to promote creativity and innovation in the organization and to acquire positive outcomes (Katishat, 2006).

Organizational relationships in modern institutions are characterized by being overlapping and interrelated. Whenever there are interactions among individuals and groups within an organization, conflicts would inevitably occur. Organizational conflict would influence employees' achievement motivation. Individuals' motivation directs their behaviors towards specific goals. Therefore, in order for the organization to achieve its goals, the organization's administrators need to manage organizational conflict to maintain moderate level of it. Moderate levels of conflicts would help organization to reach high level of achievement. Therefore, the purpose of the current was to investigate the levels of utilization of strategies for managing conflict and their relationships with the level of achievement motivation among the employees of AHU.

\subsection{Research Questions}

The present study seeks to answer the following questions:

1- What are the conflict management strategies the administration at(AHU) uses from the perspective of its employees? 


\section{Macrothink}

International Journal of Learning and Development

ISSN 2164-4063 2018, Vol. 8, No. 1

2- Are there any statistically significant differences at $\alpha(0.05)$ in employees' responses to conflict management strategies scale at AHU due to gender, job type, and experience in administrative work?

3- What is the level of achievement motivation among the employees achievement at AHU?

4- Are there any statistically significant differences at $\alpha(0.05)$ in employees' responses to achievement motivation scale at AHU due to gender, job type, and experience in administrative work?

5- Is there any statistically significant relation statistically at $\alpha(0.05)$ between the domains of conflict management strategies scale and achievement motivation among employees at AHU?

\subsection{Objectives of the Study}

The present study seeks to achieve the following objectives:

- Identifying conflict management strategies the administration at AHU uses from the perspective of its employees.

- Identifying the level of achievement motivation the employees at AHU have.

- To investigate the relation between conflict management strategies the administration at AHU uses and level of achievement motivation among employees.

\subsection{Importance of the Study}

The importance of the current study is a result of the following issues:

- The study deals with a significantly important issues as it concerns human resources which make a basic element for any institution to achieve its gools.

- The study was carried out a Jordanian state university, so it is hopeful that its results will positively affect the use of conflict management strategies by the administration university.

- Identify the level of achievement motivation indicates the level of satisfaction among employees which, in turn, helps the administration choose the best strategies.

- In the light of the results, this stud provides a set of recommendations that might hopefully have a positive impact on the process of managing organizational conflicts and on the level of achievement motivation among employees. 
1.7 Limitations of the Study

The current study has some limitations that include:

- Time limitation: The study took place in one point of time during the first semester of 2016/2017.

- Settings related limitation: The study took place in only one public university in Jordan that called Al-Hussein Bin Talal University (AHU).

- Topics related limitation: This limitation is related to the topics of the research i.e., strategies of managing the organizational conflict and the achievement motivation and the used instrument to collect related data. This limitation is related to validity and reliability of the data collection instrument and the results of the study.

\subsection{Definitions of Terms}

The adopted definitions and procedural definitions of the main terms of the study are as follow:

- Strategies for managing organizational conflicts: are behavioral methods used by administrators at AHU to mitigate and resolve conflicts. The adopted procedural definition is the score of a group of employees on a scale that was designed to measure the levels of utilization of conflict management strategies at AHU.

- Achievement motivation: The readiness and ability of employees to successfully accomplish their work tasks. The adopted procedural definition is the score of the $\mathrm{f} a$ group of employees on a scale that was designed to measure achievement motivations.

\section{Literature Review}

There are several research studies that examined conflict management and achievement motivation in an organization. The current section discusses some previous studies related to these topics. The studies are presented in chronological order.

\subsection{Organizational Conflicts}

Henkin, Gistone, and Dee, (2000) examined the preferred conflict management behaviors and strategies of a sample of school principals. The study sample consisted from 103 principals in a large, urban school district that are located in south-eastern of the United States. A questionnaire instrument was used to collect data. The results showed that school principals rarely used avoidance as a style to manage conflicts and the most used strategies for managing conflict were collaborating and advice-giving mode of problem solving.

Issa (2009) examined faculty members' perceptions of the extent of using of conflict management strategies by heads of nursing departments in Jordanian private universities and their relation to the administrative work ethics. The study sample consisted of 104 faculty members from five universities were randomly selected from the eight private universities that exist in Jordan. The study used a questionnaire with two scales: strategies of conflict 
management scale and administrative work ethics scale. In order of the level of use from the most common to the least common, the study found that used conflict management strategies, arranged in order of frequency, were collaboration, compromise, accommodation, dominance, and avoidance.

Al-Ja'afra (2013) examined the relationship between the adopted methods for managing organizational conflict and administrative creativity among principals of public schools in Karak governorate in Jordan. The researcher developed a questionnaire and used it to collected data from 225 principals. The results of the study indicated that the principals believed that the level of their use the three examined strategies for managing conflicts (collaboration, avoidance, and courtesy) were high. In addition, the results showed that there were no statistically significant differences in the participants' degree of using conflict management methods based on their gender and experience. However, there was a statistically significant difference in the participants' degree of using conflict management methods based on their academic qualifications.

Abu-Sinayna and Al-Bayati (2014) examined teachers' perceptions of the levels of utilization of conflict management strategies by the principals of the secondary schools in the Amman governorate and their relations to the levels of organizational loyalty of teachers. The study sample consisted of 200 teachers. The results showed that principals' levels of use of conflict management strategies were moderate and that the levels of organizational loyalty of the teachers were moderate. There was a statistically significant relationship between principals' levels of using conflicts management strategies and the teachers' levels of organizational loyalty.

Awaisat (2015) investigated teacher' perceptions of the levels of utilization of the conflicts management strategies by group of principals in private schools in Amman governorate in Jordan and their relations to teachers' levels of job satisfaction. The study sample consisted of 364 teachers who were randomly selected using stratified random sampling. A questionnaire instrument was used to collect data. The results showed that principals' levels of utilization of conflicts management strategies were moderate and that the levels of teacher' job satisfaction were moderate.

A review of the studies related to the organizational conflict showed that all of the examined studies were conducted in schools except for Issa's (2009) study that was conducted at the University of Jordan. In addition, these studies showed that the levels of conflicts were often moderate, and the collaborating strategy was the most widely used strategy among the organizational conflict management strategies.

\subsection{Achievement Motivation}

Othman (2010) conducted a study that aimed at identifying the professional pressures and their relation to the levels of achievement motivation among civil protection agents. The sample consisted of 100 agents. The results showed that there was negative relationship between the agents' perceptions of the levels the professional pressures and their levels of motivation to avoid failure. In addition, the results showed that there were no significant 
differences in the agents' perceptions of the levels the professional pressure based on their age and experience.

Afful-Broni,( 2012) examined the relationship between motivation and job performance. The study sample consisted of 200 staff members at the University of Mines and Technology in Ghana. A questionnaire instrument was developed by the researcher to collect data. The results showed that the staff believed that low monthly incomes and the general lack of motivation were the main factors that would negatively affect their morale and their performance at the university. The study recommended that in order to support management of the university, there was need for creating profits generating projects to contribute in providing sufficient financial motivations and grants for the staff at the university.

Asim (2013) examined the effect of motivation levels of the employees on their performances with training as a moderating variable. The sample of the study consisted of 118 employees in Pakistani universities. The results showed that these variables depend on each other's. Employees' performance and their training would significantly affect the motivation of the employees to accomplish their work tasks.

Romle, Talib, and Isa (2016) investigated the effects of motivation and commitment on job performance among university employee from the students' point of views in a public university in Malaysia. The study sample consisted from 210 graduate students. The results showed that intrinsic motivation, extrinsic motivation, and active commitment had influence on job performance. In addition, the results showed that among these factors, intrinsic motivation had the strongest relationship with job performance.

The review of studies related to achievement motivation showed that achievement motivation is affected by several factors, including: professional pressure, motivation, and the level of income and training.

\section{Research Methods}

This section presents the description of the methodology, population and sample of the study as well as the used data collection instrument in the study.

\subsection{Methodology of the Study}

The descriptive and correlation approach was used in this study. This approach has been adopted to suit the nature of the study in terms of its purpose, data collection and data analysis.

\subsection{Study Population and Sample}

The population of this study included all the university academic/administrative employees and administrative employees, where academic/administrative have joint responsibilities: academic and administrative at AHU. The study population consisted from deans, vice deans, heads of department, and unit managers. The entire population consisted from 290 employees based on statistics personnel affair department for the academic year 2016/2017. The study sample was selected using simple random sampling. The number of participants was 155 
employees. However, after examining participants' responses to the questionnaire, six responses were excluded since they were not complete. Therefore, the sample of the study consisted from 149 participants, which represent $51.5 \%$ of the study population. Table 1 shows descriptive summary of participants' demographic data.

Table 1. Descriptive summary of participants' demographic data

\begin{tabular}{|c|c|c|c|}
\hline Variables & Category & Frequency & Percent \\
\hline \multirow[t]{2}{*}{ Gender } & Male & 108 & 72.5 \\
\hline & Female & 41 & 27.5 \\
\hline \multirow[t]{2}{*}{ Job type } & Administrative employees & 98 & 65.8 \\
\hline & Academic/administrative employees & 51 & 34.2 \\
\hline \multirow[t]{3}{*}{ Years of administrative experience } & From one year to less than 5 years & 19 & 12.8 \\
\hline & $5-10$ years & 39 & 26.2 \\
\hline & More than 10 years & 91 & 61.1 \\
\hline Overall & & 149 & $100 \%$ \\
\hline
\end{tabular}

Table 1 shows that about three-quarter of the participants $(72.5 \% ; n=108)$ were male employees, while only about one-quarter of the participants $(27.5 \% ; n=41)$ were female employees. About two-third of the participants $(65.8 \% ; n=98)$ were administrative employees, while about one third of the participants $(34.2 \% ; n=51)$ were academic employees and they who had administrative jobs. The majority of participants $(61.1 \% ; n=91)$ had more than 10 years of experience in university administration, while about one quarter of the participants $(26.2 \% ; n=39)$ had 5 to 10 years of experience in university administration. Only $12.8 \%(n=19)$ had less than 5 years of experience in university administration.

\subsection{Data Collection Instrument}

In order to achieve the purpose of the study, the researchers developed a scale that includes three parts. The first part includes the demographic characteristics of the employees: gender, job type, and number of years of administrative experience. The second part consist of (27) items of conflict management strategies that administration at AHU uses from the employees perspective. The third part is(20) items that measure the levels of achievement motivation among the employees. The researchers used theoretical frameworks and previous research studies (e.g., Issa, 2009; Al-Ja'afra, 2013; Awaisat, 2015) related to conflict management in order to select and develop the items in the conflict management scale. The conflict management scale consisted from 27 items that were used to measure the levels of utilization of four management strategies, namely dominating, avoiding, collaborating, and accommodating. The achievement motivation items were selected and developed based on different related research studies (e.g., Salem, 2008; Issa, 2009; Al-Azraq, 2000). The achievement motivation scale consisted from 20 items 


\section{Macrothink}

International Journal of Learning and Development

ISSN 2164-4063 2018, Vol. 8, No. 1

\subsubsection{Validity and Reliability of the Data Collection Instrument}

In order to ensure validity of the data collection instrument, the questionnaire was checked by 10 faculty members from different Jordanian universities. These faculty members have knowledge and experience in the topics of the present study. The faculty members provided their opinions regarding each item in the questionnaire in term of the degree that the item measures what it claims to measure, the degree to which the language of each item were clear and simple, and the degree of relevance of each item to the related sub-scale or scale. The researchers included the items that 8 out of 10 reviewers believed that they were valid and relevant. Based on the reviewers' comments, all the examined items were included in the questionnaire. However, the researchers adjusted the wording of some items based on the reviewers' comments. In order to ensure the reliability of the questionnaire instrument and internal consistency of the items in the scales, Cronbach's alpha coefficients were computed for data from study. Table 2 shows the values of Cronbach's Alpha.

Table 2. Summary of reliability analysis

\begin{tabular}{ll}
\hline Scale & Cronbach's Alpha \\
\hline Conflict management scale & 0.81 \\
Dominating strategy sub-scale & 0.70 \\
Avoiding strategy sub-scale & 0.91 \\
Collaborating strategy sub-scale & 0.72 \\
Accommodating strategy sub-scale & 0.75 \\
Achievement motivation scale & 0.94 \\
\hline
\end{tabular}

Table 2 shows that the values of Cronbach's Alpha for conflict management scale and sub-scales ranged from 0.70 to 0.92. The value of Cronbach's Alpha for achievement motivation scale was 0.94 . The values of Cronbach's Alpha ranged between moderate and high. The values of Cronbach's alpha were accepted for the purpose of the study.

\section{Results and Discussion}

The current section introduces the result of this study that aims at identifying the conflict management strategies the (AHU) administration uses and their relation to employees achievement motivation according to the question of the study.

In order to explain the means of employees responses to each domain of conflict management strategies scale, the scores of the 5- point Likert scale were used. The same procedures were applied to achievement motivation scale. (Table 3) 


\section{Macrothink}

International Journal of Learning and Development

ISSN 2164-4063 2018, Vol. 8, No. 1

Table 3. The used levels to categorize the mean scores on the 5-point Likert scale

\begin{tabular}{ll}
\hline Mean scores & Level \\
\hline Between 1and 2.33 & Low \\
Between 2.34 and 3.66 & Moderate \\
Between 3.67 and 5 & High \\
\hline
\end{tabular}

The length of the interval for categorizing the mean scores on the used 5-point Likert scale was computed based on the following equation:

The length of interval $\frac{\text { highest value-lowest value }}{n}=\underline{\text { number of levels }}=\underline{3}=1.33$

4.1 First research question" What are the conflict management strategies the administration at(AHU) uses from the perspective of its employees?

In order to answer the first research question, the means and standard deviations of conflict management strategies were computed, the means and standard deviations were computed for participants' responses to each sub-scale and each item in the sub-scales of conflict management questionnaire. Table 4 shows descriptive statistics of participants' responses to the four sub-scales of conflict management scale.

Table 4. Means and standard deviation of participants' responses to the levels of utilization of conflict management strategies. $(\mathrm{N}=149)$

\begin{tabular}{lllll}
\hline $\mathbf{N}$ & Dimension & $\mathbf{M}$ & SD & Level \\
\hline 1 & Dominating strategy & 3.37 & .58 & Moderate \\
2 & Avoiding strategy & 3.24 & .57 & Moderate \\
3 & Collaborating strategy & 2.92 & .89 & Moderate \\
4 & Accommodating strategy & 2.63 & .72 & Moderate \\
\hline Overall & 3.08 & .43 & Moderate \\
\hline
\end{tabular}

Table 4 shows that participants' levels of how the AHU administration uses conflict management strategies were moderate $(M=3.08, \mathrm{SD}=0.43)$. The means of the participants' levels of using the four conflict management strategies were also moderate ranging between $(M=2.63, S D=.72)$ to $(M=3.37, S D=.58)$. 
The participants believed that the most utilized strategy was dominating while they least utilized strategy was accommodating.

The results indicated that the administrators at AHU utilize the four strategies for managing organizational conflict management: dominating, avoiding, collaborating, and accommodating at moderate levels. The administration should maintain accepted and moderate levels of conflicts at the organization in order to reach high achievements. The result was similar to the results of the Awaisat's study (2015) that found that the level of utilizing the conflict management strategies was moderate.

\subsubsection{Dominating Strategy}

Table 5. Means and standard deviation of participants' responses to the dominating strategy sub-scale. $(\mathrm{N}=149)$

\begin{tabular}{|c|c|c|c|c|}
\hline $\mathrm{N}$ & Item & $\mathrm{M}$ & SD & Level \\
\hline 4 & $\begin{array}{l}\text { The university administrators cling to their positions and opinions in the } \\
\text { process of resolving organizational conflicts }\end{array}$ & 3.62 & .91 & Moderate \\
\hline 2 & $\begin{array}{l}\text { The university administrators make decisions related the organizational } \\
\text { conflicts without consulting the employees. }\end{array}$ & 3.58 & .97 & Moderate \\
\hline 6 & $\begin{array}{l}\text { The university administrators try to keep talking during meetings to } \\
\text { avoid employees' interventions. }\end{array}$ & 3.47 & 1.04 & Moderate \\
\hline 3 & $\begin{array}{l}\text { The university administrators impose a disciplinary penalty on the } \\
\text { employees who do not follow their instructions. }\end{array}$ & 3.40 & 1.03 & Moderate \\
\hline 1 & $\begin{array}{l}\text { The university administrators use their authority to resolve } \\
\text { organizational conflicts. }\end{array}$ & 3.36 & .94 & Moderate \\
\hline 5 & $\begin{array}{l}\text { The university administrators share with the employees the } \\
\text { administrative facts to reduce organizational conflicts. }\end{array}$ & 3.30 & 1.01 & Moderate \\
\hline 7 & $\begin{array}{l}\text { The university administrators become hostile with the employees who } \\
\text { disagree with their decisions. }\end{array}$ & 2.86 & 1.21 & Moderate \\
\hline \multicolumn{2}{|c|}{ Dominating strategy } & 3.37 & .58 & Moderate \\
\hline
\end{tabular}

Table 5 shows that the overall level of using of dominating strategy at AHU was moderate ( $M$ $=3.37, S D=0.58$ ). The means of the employees' responses to all the items of the level of utilization of dominating strategy were moderate. The employees responded most positively to item 4 "The university administrators cling to their positions and opinions in the process of resolving organizational conflicts." $(M=3.62, S D=0.91)$ followed by item 2 "The university administrators make decisions related the organizational conflicts without consulting the employees." $(M=3.58, S D=.97)$.. The employees responded least positively to item 7 "The university administrators become hostile with the employees who disagree with their decisions." $(M=2.86, S D=1.21)$. 


\section{Macrothink}

The results showed the dominating strategy was labeled as moderately used by the AHU administration. The moderate use of dominating strategy reflects that the administration has higher interest in applying the university's policies and regulations rather than satisfying employees' demands.

One possible explanation of the administration's use of dominating strategy is the lack of financial resources and significant financial hardship that the university suffers form. The lack of financial resources and the financial hardship, at the university, limits the university capability to satisfy many of its employees' financial demands. Therefore, the university administrators used dominating strategy to reduce expenses and to avoid collisions with employees who the university was unable to satisfy their demands.

\subsubsection{Avoiding Strategy}

Table 6. Means and standard deviation of participants' responses to the avoiding strategy sub-scale. $(\mathrm{N}=149)$

\begin{tabular}{lllll}
\hline $\mathrm{N}$ & Items & $\mathrm{M}$ & $\mathrm{SD}$ & Level \\
\hline 8 & $\begin{array}{l}\text { The university administrators' interaction with employees is limited } \\
\text { to formal matters. }\end{array}$ & 3.56 & 1.12 & Moderate \\
2 & $\begin{array}{l}\text { The university administrators avoid initiating open discussion with } \\
\text { the employees who disagree with their policies and decisions. }\end{array}$ & 3.40 & 1.10 & Moderate \\
$5 \begin{array}{l}\text { The university administrators do not consider the opposing } \\
\text { viewpoints. }\end{array}$ & 3.35 & .980 & Moderate \\
$1 \quad \begin{array}{l}\text { The university administrators do not consider the opposing } \\
\text { viewpoints ignore the causes of organizational conflicts. }\end{array}$ & 3.22 & 1.03 & Moderate \\
3 & $\begin{array}{l}\text { The university administrators avoid taking decisions that cause } \\
\text { controversy among employees. }\end{array}$ & 3.18 & .98 & Moderate \\
7 & $\begin{array}{l}\text { The university administrators try to prevent employees from showing } \\
\text { their feelings of anger toward its decisions. }\end{array}$ & 3.14 & 1.11 & Moderate \\
$4 \begin{array}{l}\text { The university administration tries to prevent horizontal } \\
\text { communication among the employees in order to avoid the } \\
\text { organizational conflicts. }\end{array}$ & 3.08 & 1.03 & Moderate \\
$\begin{array}{l}\text { The university administration provides stress-free and positive } \\
\text { workplace environment to minimize organizational conflicts. }\end{array}$ & 3.01 & 1.12 & Moderate \\
\hline Avoiding strategy & 3.24 & .570 & Moderate \\
\hline
\end{tabular}

Table 6 shows that the overall level of utilization of avoiding strategy at AHU was moderate $(M=3.24, S D=0.57)$. The means of the employees' responses to all the items of the level of utilization of avoiding strategy were moderate. The employees responded most positively to item 8 "The university administrators' interaction with employees is limited to formal matters." ( $M=3.01, S D=1.12)$, followed by item 2 "The university administrators avoid 


\section{Macrothink}

International Journal of Learning and Development

ISSN 2164-4063

2018, Vol. 8, No. 1

initiating open discussion with the employees who disagree with their policies and decisions." ( $M=3.40, S D=1.10)$. The employees responded least positively to item 6 "The university administration provides a positive workplace environment to minimize organizational conflicts." $(M=3.01, S D=1.12)$.

The results showed the avoiding strategy was labeled as moderately used by the AHU administration. The avoiding strategy involves the administration ignoring the conflicts, where the administrators perceive that conflicts will be resolved as time goes.

The administrators at AHU utilized avoiding strategy at moderate level in order to stay away from the sources and causes of conflicts, where conflicts might negatively affect the extent of achieving the university goals and the accomplishing of the work tasks. Therefore, the administrators at AHU try to avoid disagreement with the employees and they stay away from the sources of conflicts.

\subsubsection{Collaborating Strategy}

Table 7. Means and standard deviation of participants' responses to the collaborating strategy sub-scale. $(\mathrm{N}=149)$

\begin{tabular}{|c|c|c|c|c|}
\hline $\mathrm{N}$ & Items & M & SD & Level \\
\hline 1 & $\begin{array}{l}\text { The university administrators work with the employees to reach a } \\
\text { common understanding of the causes of organizational conflicts. }\end{array}$ & 3.24 & .96 & Moderate \\
\hline 7 & $\begin{array}{l}\text { The university administrators work to control the disagreements between } \\
\text { the employees in order to mitigate organizational conflicts. }\end{array}$ & 3.11 & 1.04 & Moderate \\
\hline 3 & $\begin{array}{l}\text { The university administration works with the employees to set goals that } \\
\text { can be accomplished only with the collaboration between the } \\
\text { administrators and the employees at the university. }\end{array}$ & 3.05 & 1.06 & Moderate \\
\hline 2 & $\begin{array}{l}\text { The university administration works collaboratively with the employees } \\
\text { to make decisions to resolve organizational conflicts }\end{array}$ & 2.87 & 1.03 & Moderate \\
\hline 4 & $\begin{array}{l}\text { The university administrators are devoted to investigate the employees' } \\
\text { administrative problems in order to resolve them. }\end{array}$ & 2.86 & 1.13 & Moderate \\
\hline 6 & $\begin{array}{l}\text { The university administration reconciles the different perspectives of the } \\
\text { conflict parties in order to suit each party. }\end{array}$ & 2.85 & 1.06 & Moderate \\
\hline 5 & $\begin{array}{l}\text { The university administration provides incentives to encourage } \\
\text { employees to collaborate with the administrators effectively. }\end{array}$ & 2.43 & 1.36 & Moderate \\
\hline \multicolumn{2}{|c|}{ Collaborating strategy } & 2.92 & .89 & Moderate \\
\hline
\end{tabular}

Table 7 shows that the overall level of utilization of collaborating strategy at AHU was moderate $(M=2.92, S D=0.89)$. The means of the employees' responses to all the items of the level of utilization of collaborating strategy were moderate. The employees responded most positively to item 1 "The university administrators work with the employees to reach a common understanding of the causes of organizational conflicts." $(M=3.24, S D=0.96)$, 
followed by item 7 "The university administrators work to control the disagreements between the employees in order to mitigate organizational conflicts." $(M=3.11, S D=1.04)$. The employees responded least positively to item 5 "The university administration provides incentives to encourage employees to collaborate with the administrators effectively." $(M=$ 2.43, $S D=1.36)$.

The results showed the collaborating strategy was labeled as moderately used by the AHU administration. The collaborating strategy involves identifying and discussing the sources of conflicts, identifying and focusing on the common interests of the conflicting parties, arranging meeting between conflicting parties in order to reach common understandings, and working on resolving the conflicts using appropriate methods to satisfy the interests of all parties. The administrators at AHU utilized collaborating strategy at moderate level in order to achieve the benefits for the university and employees. The use of collaborating strategy at AHU was clear in forms of holding meetings and conference with employees, allowing the employees to express their opinions and suggestions, making the employees know about the financial capabilities of the university, and emphasizing on the fact that that the university and employees are seeking to accomplish common higher level goals that serve the general interests of the university.

\subsubsection{Accommodating Strategy}

Table 8. Means and standard deviation of participants' responses to the accommodating strategy sub-scale. $(\mathrm{N}=149)$

\begin{tabular}{lllll}
\hline $\mathbf{N}$ & Items & M & SD & Level \\
\hline 1 & $\begin{array}{l}\text { Sometimes the university administrators revoke some of the } \\
\text { decisions that have been made for the sake of satisfying the } \\
\text { employees. }\end{array}$ & 2.85 & 1.01 & Moderate \\
5 & $\begin{array}{l}\text { The university administrators leave the responsibility to } \\
\text { conflicting parties to resolve their conflicts. }\end{array}$ & 2.77 & 1.09 & Moderate \\
2 & $\begin{array}{l}\text { The administrators work to meet the employees' demands to } \\
\text { prevent conflicts within the university }\end{array}$ & 2.77 & .91 & Moderate \\
3 & $\begin{array}{l}\text { The university administrators leave the task of making decisions } \\
\text { about organizational conflict to the employees. }\end{array}$ & 2.46 & .96 & Moderate \\
& $\begin{array}{l}\text { The university administration acts for the benefits of the } \\
\text { employees rather than acting in its own best interests }\end{array}$ & 2.32 & 1.06 & Low \\
\hline Accommodating strategy & 2.63 & .72 & Moderate \\
\hline
\end{tabular}

Table 8 shows that the overall level of utilization of accommodating strategy at AHU was moderate $(M=2.63, S D=0.72)$. The means of the employees' responses to the items of the level of utilization of accommodating strategy varied between low and moderate. The employees responded most positively to item 1 "Sometimes the university administrators 


\section{Macrothink}

revoke some of the decisions that have been made for the sake of satisfying the employees." $(M=2.85, S D=1.01)$, followed by item 5 "The university administrators leave the responsibility to conflicting parties to resolve their conflicts." $(M=2.77, S D=1.09)$. The employees responded least positively to item 4 "The university administration acts for the benefits of the employees rather than acting in its own best interests." $(M=2.32, S D=1.06)$.

The means of the employees' responses to all the items of the level of utilization of accommodating strategy were moderate except for one item. The administrators at AHU utilized accommodating strategy at moderate level. The accommodating strategy involves the administration working collaboratively with the employees in order to adapt and adjust to their needs. In addition, accommodating strategy involves the administration showing greater interest in employees' interests rather than focusing only on its own benefits.

The administrators at AHU give the employees the chance to express their opinions and sometimes they follow the employees' opinions to resolve conflicts. The administrators at AHU utilized at accommodating strategy in order to maintain moderate management rather than strict one and to avoid tension between administration and employees that might negatively influence the general interests of the university. Some employees' demands would be significant for them and the administration' failure to satisfy these demands might cause intense conflicts with these employees. Therefore, administration worked to satisfy the employees' needs and demands. In addition, the administration had changed some decisions to avoid collisions with the employees or to affect the course of university work.

4.2 Second Research Question "Are there any statistically significant differences at $\alpha(0.05)$ in employees' responses to conflict management strategies scale at AHU due to gender, job type, and experience in administrative work?

In order to answer the second research question regarding the variations in participants' levels of utilization of conflict management strategies at AHU based on their gender, job type, and number of years of administrative experience; the means and standard deviations of the employees' responses to the to the four conflict management strategies sub- scales were computed based on these variables. (See Tables 9-11.) 


\section{Macrothink}

International Journal of Learning and Development

ISSN 2164-4063 2018, Vol. 8, No. 1

Table 9. Means and standard deviations for conflict management strategies scale at AHU due to gender and job type

\begin{tabular}{|c|c|c|c|c|c|c|c|c|c|c|}
\hline \multirow[t]{3}{*}{ Strategy } & \multicolumn{4}{|c|}{ Gender } & \multicolumn{6}{|c|}{ Management experience year } \\
\hline & \multicolumn{2}{|l|}{ Male } & \multicolumn{2}{|c|}{ Female } & \multirow[b]{2}{*}{ Mean } & \multirow[b]{2}{*}{ SD } & \multirow[b]{2}{*}{ Mean } & \multirow[b]{2}{*}{ SD } & \multirow[b]{2}{*}{ Mean } & \multirow[b]{2}{*}{ SD } \\
\hline & Mean & SD & Mean & $\mathrm{SD}$ & & & & & & \\
\hline Dominating & 3.40 & .62 & 3.28 & .45 & 3.14 & .69 & 3.32 & .48 & 3.44 & .59 \\
\hline Avoiding & 3.01 & .94 & 2.66 & .70 & 3.12 & .94 & 3.17 & .72 & 2.76 & .92 \\
\hline Collaborating & 3.25 & .60 & 3.21 & .45 & 3.07 & .73 & 3.22 & .48 & 3.28 & .56 \\
\hline Accommodating & 2.69 & .73 & 2.47 & .67 & 2.65 & .72 & 2.68 & .64 & 2.61 & .76 \\
\hline Overall & 3.13 & .47 & 2.95 & .30 & 3.02 & .50 & 3.13 & .34 & 3.06 & .46 \\
\hline
\end{tabular}

Table 10. Means and standard deviations for employees' perceptions of the levels of utilization of conflict management strategies at AHU due to job type

\begin{tabular}{lllll}
\hline Strategy & \multicolumn{2}{c}{ Administrative } & \multicolumn{2}{c}{ Academic/administrative } \\
\cline { 2 - 5 } & Mean & SD & Mean & SD \\
\hline Dominating & 3.46 & .580 & 3.19 & .540 \\
Avoiding & 2.78 & .940 & 3.17 & .740 \\
Collaborating & 3.30 & .540 & 3.12 & .600 \\
Accommodating & 2.59 & .750 & 2.73 & .640 \\
Overall & 3.08 & .460 & 3.08 & .380 \\
\hline
\end{tabular}

Tables 9-10 shows that there were differences in the means of employees' perceptions of the levels of utilization of conflict management strategies at AHU based on their gender, job type, and number of years of administrative experience, Analysis of variance (ANOVA) was conducted to examine whether these differences were statistically significant at $(\alpha<0.05)$ (Table 12). 
Table 11. One-Way ANOVA- employees' responses to four sub-scales of conflict management scale based on their gender, job type, and number of years of administrative experience

\begin{tabular}{|c|c|c|c|c|c|c|}
\hline & Strategy & $\begin{array}{l}\text { Sum } \\
\text { Squares }\end{array}$ & $\begin{array}{ll}\text { Degree } & \text { of } \\
\text { Freedom } & \end{array}$ & $\begin{array}{l}\text { Mean } \\
\text { Square }\end{array}$ & $\mathbf{F}$ & Sig. \\
\hline \multirow[t]{5}{*}{ Gender } & Dominating & .920 & 1 & .92 & 2.86 & .09 \\
\hline & Avoiding & 2.66 & 1 & 2.66 & 3.55 & .06 \\
\hline & Collaborating & .210 & 1 & .21 & .660 & .42 \\
\hline & Accommodating & 1.25 & 1 & 1.25 & 2.44 & .12 \\
\hline & Overall & 1.03 & 1 & 1.03 & 5.57 & .68 \\
\hline \multirow[t]{5}{*}{ Job type } & Dominating & 1.45 & 1 & 1.45 & 4.49 & .63 \\
\hline & Avoiding & .990 & 1 & .99 & 1.32 & .25 \\
\hline & Collaborating & .650 & 1 & .650 & 2.06 & .15 \\
\hline & Accommodating & .390 & 1 & .390 & .76 & .39 \\
\hline & Overall & .030 & 1 & .03 & .17 & .68 \\
\hline \multirow{5}{*}{$\begin{array}{l}\text { Years of administrative } \\
\text { experience }\end{array}$} & Dominating & .300 & 2 & .15 & .46 & .63 \\
\hline & Avoiding & 1.97 & 2 & .99 & 1.31 & .27 \\
\hline & Collaborating & .200 & 2 & .100 & .31 & .73 \\
\hline & Accommodating & .130 & 2 & .070 & .13 & .88 \\
\hline & Overall & .280 & 2 & .140 & .740 & .48 \\
\hline \multirow[t]{5}{*}{ Error } & Dominating & 46.51 & 144 & .320 & & \\
\hline & Avoiding & 108.03 & 144 & .750 & & \\
\hline & Collaborating & 45.62 & 144 & .320 & & \\
\hline & Accommodating & 74.06 & 144 & .510 & & \\
\hline & Overall & 26.65 & 144 & .190 & & \\
\hline
\end{tabular}

Table 11 shows that there were no statistically significant differences at $(\alpha<0.05)$ in the means of the employees' responses to the four sub-scales, that measured the levels of utilization of conflict management strategies at AHU, based on their gender, job type, and number of years of administrative experience

This result can be explained based on the fact that all the participants were employees at one university. They work under the same organizational environment and same working conditions. All participants follow one university's regulations and rules. The findings of the current study aligned with the findings of Al- Ja'afra's (2013) study. 
4.3 Third research question " What is the level of achievement motivation among the employees achievement at AHU?

In order to answer the third research question regarding the participants' levels of achievement motivation at AHU, the means and standard deviations of participants' responses to each item of the achievement motivation scale were computed (Table 12).

Table 12. Means and standard deviations of participants' responses to achievement motivation scale. $(\mathrm{N}=149)$

\begin{tabular}{|c|c|c|c|c|}
\hline $\mathbf{N}$ & Items & $\mathbf{M}$ & SD & Level \\
\hline 11 & I take responsibility for what I do. & 4.65 & 0.64 & High \\
\hline 8 & I am constantly trying to develop my performance at work & 4.47 & 0.70 & High \\
\hline 12 & I try to accomplish work tasks in perfect way. & 4.44 & 0.68 & High \\
\hline 18 & I am proud of my capability to accomplish work tasks. & 4.43 & 0.65 & High \\
\hline 10 & I accept to do tasks that need extra efforts to accomplish them. & 4.40 & 0.79 & High \\
\hline 15 & $\begin{array}{l}\text { I work hard to accomplish work tasks despite the difficulties in the } \\
\text { work environment. }\end{array}$ & 4.37 & 0.65 & High \\
\hline 19 & I feel happy when important work tasks are assigned to me. & 4.32 & 0.77 & High \\
\hline 2 & I feel that the time pass so fast when I am at work. & 4.32 & 0.90 & High \\
\hline 7 & I finish the work tasks on time. & 4.32 & 0.72 & High \\
\hline 17 & I finish my work tasks with highest standards. & 4.31 & 0.66 & High \\
\hline 9 & I try hard to earn a job promotion. & 4.30 & 0.89 & High \\
\hline 20 & I do my best to finish extra work tasks free of charge. & 4.28 & 0.80 & High \\
\hline 16 & I become very determined when I have challenging tasks at work. & 4.26 & 0.76 & High \\
\hline 3 & $\begin{array}{l}\text { My plans to accomplish work tasks are usually successfully } \\
\text { implemented. }\end{array}$ & 4.21 & 0.64 & High \\
\hline 6 & I have many ambitions that I am trying to achieve in my work. & 4.20 & 0.96 & High \\
\hline 13 & I can overcome the different types of problems that I face at work. & 4.20 & 0.71 & High \\
\hline 14 & $\begin{array}{l}\text { I change my work style when I do not achieve the required level of } \\
\text { performance. }\end{array}$ & 4.15 & 0.77 & High \\
\hline 4 & $\begin{array}{l}\text { I compete against my colleagues in accomplishing high quality } \\
\text { outcomes. }\end{array}$ & 4.06 & 0.89 & High \\
\hline 1 & I am never bored when I am doing my work tasks. & 4.05 & 0.87 & High \\
\hline 5 & I use all the working time to accomplish job-related tasks. & 4.01 & 0.84 & High \\
\hline \multicolumn{2}{|c|}{ Overall achievement motivation scale. } & 4.28 & 0.53 & High \\
\hline
\end{tabular}

Table12 shows that the overall level of achievement motivation of the employees at AHU was 


\section{Macrothink}

International Journal of Learning and Development

ISSN 2164-4063 2018, Vol. 8, No. 1

high $(M=4.28, S D=0.53)$. The means of the employees' responses to all the items of the achievement motivation scale were high. The employees responded most positively to item 11 "I take responsibility for what I do." $(M=4.65, S D=.64)$, followed by item 8 "I am constantly trying to develop my performance at work." $(M=4.47, S D=.70)$. The employees responded least positively to item 5"I use all the working time to accomplish job-related tasks." $(M=4.01, S D=.53)$.

The high level of achievement motivation of AHU employees can be attributed to their high level of intrinsic motivations that encourage them to accomplish work tasks with highest standards. In addition, the employees of the university are well prepared and highly qualified to carry out their work tasks successfully. Furthermore, the employees' high level of achievement motivation can be attributed to their understanding of their job duties, required behavior and activities to accomplish their work tasks, and how they should accomplish their tasks.

4.4 Fourth research Question "Are there any statistically significant differences at $\alpha(0.05)$ in employees' responses to achievement motivation scale at AHU due to gender, job type, and experience in administrative work?"

In order to answer the fourth research question regarding the differences in employees' achievement motivation in relation to gender, job type, and number of years of administrative experience, the means and standard deviations of the employees' responses to the achievement motivation scale were computed based on these variables. (Table 13)

Table 13. Means and standard deviations of employees' level of achievement motivation due to gender, job type, and number of years of administrative experience

\begin{tabular}{llll}
\hline Variables & Options & Mean & SD \\
\hline Gender & Male & 4.33 & 0.50 \\
& Female & 4.16 & 0.58 \\
Job type & Administrative & 4.24 & 0.57 \\
& Academic/administrative & 4.37 & 0.42 \\
Years of & From one year to less than 5 years & 4.40 & 0.40 \\
Management? & 5-10 years & 4.38 & 0.42 \\
Experience & More than 10 years & 4.22 & 0.58 \\
& & & \\
\hline
\end{tabular}


Tables 13 shows that there were differences in the means of employees' levels of achievement motivation in relation to gender, job type, and number of years of administrative experience, ANOVA was conducted to examine whether these differences were statistically significant at $(\alpha<0.05)$ (Table 15).

Table 14. One-Way ANOVA- employees' responses to the achievement motivation scale based on their gender, job type, and number of years of administrative experience

\begin{tabular}{lllllc}
\hline Variables & Sum of & Degree of & Mean & F & Sig. \\
& Squares & Freedom & Square & & \\
\hline Gender & .65 & 1 & .65 & 2.38 & .13 \\
Job title & .04 & 1 & .04 & .14 & .71 \\
Years of Management Experience & .42 & 2 & .21 & .78 & .46 \\
Error & 39.1 & 144 & .27 & & \\
Overall & 2775.63 & 149 & & & \\
\hline
\end{tabular}

Table 14 shows that there were no statically significant differences at $(\alpha<0.05)$ in the means of the employees' responses to the achievement motivation scale based on their gender, job type, and number of years of administrative experience. The results showed that AHU employees had high level of achievement motivation regardless of their gender, job type, and number of years of management experience.

The insignificant difference in employees' level of achievement motivation due to their gender can be attributed to the justice and equality adopted by AHU's administrators. The male and female employees have the same work rights and they are working in the same working conditions. Promoting justice and equality in the work environment make the employees have high level of motivation to accomplish their work tasks in discrimination free environment. The adopted justice and equality adopted by AHU contribute in the insignificant difference in employees' perceptions of their level of achievement motivation based on their job type. The employees have similar rights and each of them has clear job description, these make each one understand his/her responsibilities and duties and motivated to accomplish these duties.

The insignificant difference in employees' level of achievement motivation due to their number of years of administrative experience can be explained by the fact that the employees have high level of achievement motivation. The employees with low number of years of administrative experience work hard to show their value and distinction at work, while the employees with high number of years of administrative experience have gained enough experiences and qualifications to be distinctive in their work. 


\section{Macrothink}

International Journal of Learning and Development

ISSN 2164-4063 2018, Vol. 8, No. 1

4.5 Fifth Research Question "5- Is there any statistically significant relation at $\alpha(0.05)$ between the domains of conflict management strategies scale and achievement motivation among employees at AHU?

In order to answer the fifth research question Pearson Product Moment correlations were used to examine the relationships between the four dimensions of conflict management scale (i.e., Dominating, Avoiding, Collaborating, and Accommodating) and the achievement motivation scale Table 15.

Table 15. The Correlations between conflict management strategies and the achievement motivation

\begin{tabular}{lll}
\hline Strategy & Pearson correlation coefficient value & $\mathrm{p}$ \\
\hline Dominating strategy & 0.13 & 0.11 \\
Avoiding strategy & 0.29 & $0.00^{*}$ \\
Collaborating strategy & -0.03 & 0.68 \\
Accommodating strategy & -0.12 & 0.88 \\
Overall conflict management scale & 0.18 & $0.03^{*}$ \\
\hline
\end{tabular}

* Statistical significance at the level of significance $(\alpha=0.05)$.

The correlation tests show that there were significant relationship between the avoiding strategy and achievement motivation $(r=.29, p<.01)$. The result indicted that there was positive but low relationship between the use of avoiding strategy and achievement motivation. However, that there were no significant relationship between the use of three conflict management strategies (i.e., Dominating, Collaborating, and Accommodating) and achievement motivation.

The results suggest that the higher level of achievement motivation of the university employees is associated with higher level of adoption avoiding strategy to manage the organizational conflicts by the university administration. The avoiding strategy involves the administration staying away from the causes and sources of conflicts and avoiding conflicts with the employees so that the sources of conflict gradually disappear.

\section{Recommendations}

In light of the purpose and results of the study, the researchers recommend the following:

1. The administration should maintain an average level of conflicts within the university to raise the level of achievement motivation of the employees.

2. The university should form a committee consisted from academics and administrators employees in order to identify the meet demands of the employees as well as to identify and overcome the problems they face at work. 


\section{Macrothink Institute ${ }^{T M}$}

3. The university administration should work to transform the organizational conflict into a fruitful competition for the interest of the university and to achieve its goals.

4. The university should coordinate consultation meeting between the administrators and the employees to exchange work-related views.

5. The university administration should conduct lectures and seminars to raise the awareness of the university administrators and the employees about the positive affects of conflicts, the inevitability of conflicts, and the available strategies to manage organizational conflicts.

6. The administration should transform the positive outcomes of the conflict into employees' positive energy, in order to make them show capabilities that do not appear in normal circumstances.

7. The administration should conduct regular meetings between administrators and employees to generate ideas to solve work-related problems; making conflicts a strategy to build creativity, innovation and motivation at the university.

8. The administration should employ motivation system, which includes financial and non-financial rewards, for the employees. Motivation system would have positive influence on employees' performance and achievement.

\section{References}

Ababneh, S. (1996). Methods of conflict management in public universities in Jordan from the point of view of teaching staff (Unpublished Master Thesis, Yarmouk University, Irbid, Jordan).

Ababneh, T. (1995). Conflict Management Methods: Comparative SDudy between Public and Private Sector Managers in Jordan, Applied SDudy on Irbid Governorate (Unpublished Master Thesis, University of Jordan, Amman, Jordan).

Abbas, S. (2002). Human Resources Management. Dar Wael Printing \& Publishing, Amman: Jordan.

Abdulah, M. (2003). Social behavior and dynamics - an explanatory attempt. Dar al-Maarifa al-Jami'ya, Alexandria-Egypt.

Abu-Sinayna, A., \& Al-Bayati, A. (2014). Management of the Organizational Conflict of the Principles of Public High Schools and its Relation to the Level of Organizational Loyalty of Workers in the Capital Governorate. Journal of Educational Sciences, 10 (1).

Afful-Broni, A. (2012). Relationship between Motivation and Job Performance at the University of Mines and Technology,Tarkwa, Ghana: Leadership Lessons. Creative Education, 3(3), 309-314. https://doi.org/10.4236/ce.2012.33049

Agwu, O. (2013). Conflict Management and Employees Performance in Julios Berger Nigeria PLC. Bonny Island. International Journal of Academic Research Management, 2(4), 128. 


\section{Macrothink}

Al- Mograbi, K. (1994). Organizational Behavior Concepts and Principles (2nd ed.). Dar Al Fikr for Printing, Publishing and Distribution, Amman: Jordan.

Al-Azraq, A. (2000). Educational Psychology for Teachers. Beirut, Lebanon: Arab Thought House.

Al-Balbisi, S. (2003). Conflict strategies used by general secondary school principals in Jordan and their relation to teacher morale and organizational commitment (unpublished doctoral thesis, Amman Arab University, Jordan).

Al-Bernouti, S. (2004). Human Resource Management \& Personnel Management. (2) Wael Printing \& Publishing House. Amman: Jordan.

Al-Haji, O. (1996). Development of motivation for achievement, experimental study on a sample of students of middle stage in Riyadh (unpublished master thesis, King Saud University).

Al-Hamed, M. (1996). Measuring the motivation of the educational achievement in Saudi Arabia. Magazine Gulf Message, 58.

Al-Harbi, Q. (2008). Effective School Management for Future School. Jordan, Amman: Al-Janadya House.

Al-Ja'afra, S. (2013). Methods of Organizational Conflict Management and its Relationship to Administrative Creativity among the Directors of Public Schools in Karak Governorate from their Perspective. Journal of Educational Sciences SDudies, 40(2).

Al-Momani, W. (2011). Organizational Climate and Conflict Management in Educational Institutions (2nd ed.). Dar Al-Hamed Publishing, Amman

Al-Omayan, M. (2002). Organizational Behavior in Business Organizations (1st ed.). Jordan, Amman: Dar Wael Publishing and Distribution.

Al-Omayan, M. (2005). Organizational Behavior in Business Organizations (2nd ed.). Jordan, Amman: Dar Wael Publishing and Distribution.

Al-Otaibi, T. (2006). Organizational conflicts and methods of dealing with them, a survey of the views of the officers of the General Directorate of Passports (Riyadh, Master Thesis, Naif University for Security Sciences, Riyadh, Saudi Arabia).

Al-Zayat, M. (1988). The Motivation for Achievement and Belonging among the Over-educated and Disadvantaged SDudents from High School. Educational and Psychological Research Center, (Umm Al-Qura University, Makkah Al-Mokarma).

Asim, M. (2013). Impact of Motivation on Employee Performance with Effect of Training: Specific to Education Sector of Pakistan. International Journal of Scientific and Research Publications, 3(9), 1-9.

Awaisat, Z. (2015). The Level of Organizational Conflict Management SDrategies Practiced by Principals in The Capital Amman Governorate and Their Relationship to Job Satisfaction 


\section{Macrothink}

International Journal of Learning and Development

ISSN 2164-4063 2018, Vol. 8, No. 1

Among Teachers From Their Point Of View (Unpublished Master Thesis, Middle East University, Amman, Jordan).

Ayazra, M., \& Beni-Ahmed, M. (2008). Conflict Management, Crisis and Work SDress. Jordan, Amman: Dar Al-Hamed Publishing and Distribution.

Ghbari, Th. (2008). Theoretical Motivation and Application. Jordan, Amman: Dar Al-Hamed Publishing and Distribution.

Hamoud, M. (2002). Organizational Behavior. Jordan, Amman: Dar Safa for Publishing and Distribution.

Harem, H. (2006). Organization Design, Organizational SDructure and Procedures. Jordan, Amman: Dar Al Hamed Publishing House.

Harem, H. (2004). Organizational Behavior, Behavior of Individuals and Groups in Business Organizations. Jordan, Amman: Al-Hamed Publishing House and Publishing House.

Hassan, R. (1999). Behavior in Organizations. Egypt, Alexandria: University House.

Henkin, A. Gistone,p. and Dee,J.(2000) Conflict Management SDategies of principals in Site-based Manager School. Journal of Education Administration, 38(2), 142-158. https://doi.org/10.1108/09578230010320109

Hilal, M., (1996). The Leadership Skills of Others, Egypt, Cairo: Dar Al Ketub.

Idris, T., \& Morsi, J. (2003). Organizational Behavior: Theories, Models and Practical Application of Behavior Management in the Organization. University House.

Issa, I. (2009). Organizational Conflict Management SDrategies and Their Relation to the Ethics of Administrative Work of Heads of Departments of Nursing Colleges in Private Universities from the Point of View of Teaching Staffs (Unpublished Master Thesis, Middle East University for Graduate SDudies, Amman, Jordan).

Jones, G. (1995). Organizational Theory- text and cases. New York: Addison Wesley, publishing co.

Katishat, L. (2006). Conflict Management in Educational Institutions (1st ed.). Amman: Jordan: Academic Book Center.

Khalifa, A. (2000). The motivation for achievement. Dar-Gharib, Cairo

Mustafa, A. (2000). Department of Organizational Behavior, Contemporary Perspective, Author Publisher, Cairo.

Othman, M. (2010). Professional Pressures and Their Relation to The Motivation of Achievement of Civil Protection Agents. (Unpublished Master Thesis. Al-Akhwa Mentouri University, Algeria).

Owens, R. (1981). Organizational Behavior in Education, Englewood Cliffs. NewJersey: Prentice- hull,Inc 


\section{Macrothink}

International Journal of Learning and Development

ISSN 2164-4063 2018, Vol. 8, No. 1

Robbins, S. (2001). Managing Conflict in Organiztion (3rd ed.). WestPoint: Green Wood Publishing.

Romle,A., Talib, N., \& Isa, N. (2016).The relationship between motivation and commitment on job performance among employees from students' perspective: the case in public university. Journal of Scientific Research and Development, 3(5), 43-50.

Salem, R. (2008). The relationship of self-efficacy and academic branch and academic achievement by the students of Ajloun University College. Journal of Educational and Psychological Research, 23.

Taha, F. (2003). Encyclopedia of Psychology and Psychoanalysis. Cairo, Egypt: Dar Ghraib for Printing and Publishing.

\section{Copyright Disclaimer}

Copyright for this article is retained by the author(s), with first publication rights granted to the journal.

This is an open-access article distributed under the terms and conditions of the Creative Commons Attribution license (http://creativecommons.org/licenses/by/4.0/). 